\title{
WADAH PERTUNJUKAN SENI DI BEKASI
}

\author{
Vicosta Christy ${ }^{1)}$, Tatang Hendra Pangestu ${ }^{2)}$
}

1) Program Studi S1 Arsitektur, Fakultas Teknik, Universitas Tarumanagara, vicostaac@gmail.com

2) Program Studi S1 Arsitektur, Fakultas Teknik, Universitas Tarumanagara, tatang_pangestu@hotmail.com

\begin{abstract}
Abstrak
Kota Bekasi sering disebut dengan kota komuter. Komuter adalah seseorang yang bepergian ke suatu kota untuk bekerja dan kembali ke kota tempat tinggalnya setiap hari, biasanya dari tempat tinggal yang cukup jauh dari tempat bekerjanya. Tidak ada hal yang menarik untuk mengajak para pelancong ke kota ini. Kota ini adalah rumah bagi jutaan penduduk yang sebagian besar bekerja di ibukota Jakarta. Alasannya mudah, karena Jakarta sudah sesak dan harga satu unit tempat tinggal di Jakarta sudah meroket. Masyarakat Bekasi memiliki mobilitas yang tinggi. Mereka berangkat dari pagi dan kembali saat hari sudah gelap. Rumah hanya dijadikan untuk beristirahat saja. Tidak terdapat tren kebudayaan di Bekasi sekaligus ruang bersama untuk warga saling berkomunikasi dan menuangkan minat bakatnya. Perlu adanya sebuah wadah untuk merangkul polaritas kota dengan alam untuk hidup berdampingan supaya menghasilkan lingkungan yang lebih menarik dan mengakomodasi kota Bekasi menjadi tempat rekreasi edukatif, menggabungkan nilai sosiabilitas dan relaksasi. Ruang ketiga menjadi peran yang bisa berkontribusi dengan keseluruhan gaya hidup masyarakat. Untuk itu masyarakat perlu menyadari bahwa, ruang ketiga menjadi aset yang tidak dapat diperdebatkan. Konsep ruang ketiga ini cukup unik untuk proses perkembangan sebuah tempat, karena ruang ketiga menerobos sebuah generasi dengan kesepakatan yang jauh lebih baik daripada karakteristik tempat lain. Proyek ini menggunakan metode trans programming untuk program di dalam proyek dan metode tipologi bangunan dimana akan menganalisa beberapa aspek pada bangunan - bangunan ruang pertunjukan dari terdahulu hingga kekinian. Konsep utama bangunan ini mengutamakan fleksibilitas ruang sehingga bisa digunakan untuk beberapa kegiatan yang berbeda.
\end{abstract}

Kata kunci: fleksibilitas; kebudayaan; komuter; ruang ketiga; tipologi

\begin{abstract}
Bekasi is referred to commuter city. A commuter is someone who travels to a city to work and returns to his hometown every day, usually from a place that is quite far from where he works. There is nothing interesting to invite travelers to this city. The city is home to millions of residents who mostly work in the capital city of Jakarta. The reason is because Jakarta is already overcrowded and the price of a residential unit in Jakarta has escalated. Bekasi society has high mobility. They departed from morning and returned when it was dark. The house is only used as a rest. There is no cultural trend in Bekasi as well as a shared space for residents to communicate with each other and express interest in their talents. There needs to be a forum to embrace the polarity of the city with nature to coexist in order to produce a more attractive environment and accommodate the city of Bekasi as an educational recreation area, combining the value of sociability and relaxation. The third place becomes a role that can contribute to the overall lifestyle of the community. For this reason, people need to realize that the third space is an undisputable asset. The concept of this third space is quite unique for the process of developing a place, because the third space breaks through a generation with a much better deal than the characteristics of other places. This project uses the trans programming method for the program in the project and the building typology method which will analyze several aspects of the performing arts buildings from the past to the present. The main concept of this project prioritizes the flexibility of space so that it can be used for several different activities.
\end{abstract}

Keywords: commuter; culture; flexibility; third place; typology 


\section{PENDAHULUAN}

Kota Bekasi sering disebut dengan kota komuter. Tidak ada hal yang menarik untuk mengajak para pelancong ke kota ini. Meski berada di Jawa Barat, Bekasi pun tidak punya kesamaan ciri khas mengenai budaya atau kuliner. Kota ini adalah rumah bagi jutaan penduduk yang sebagian besar bekerja di ibukota Jakarta. Alasannya mudah, karena Jakarta sudah sesak dan harga satu unit tempat tinggal di Jakarta sudah meroket. Maka dari itu masyarakat Bekasi yang bekerja di ibukota seringkali disebut masyarakat komuter.

Komuter sendiri adalah ungkapan tentang seseorang yang pergi ke luar kota untuk beraktivitas.(Rahman,2015,p.1.) Sebenarnya jarak Bekasi dan Jakarta tidak jauh, serta dihubungkan dengan berbagai akses. Hanya saja jumlah kendaraan mobil yang masuk ke Jakarta inilah yang membuat masyarakat Bekasi berangkat lebih pagi. Masyarakat Bekasi memiliki mobilitas yang tinggi. Mereka berangkat dari pagi dan kembali saat hari sudah gelap. Rumah hanya dijadikan untuk beristirahat saja. Secara visual wujud lingkungan, terdapat kecenderungan yang kurang positif bahwa sebagian kawasan perumahan dan permukiman telah mulai bergeser menjadi lebih tidak teratur, kurang berjati diri, dan kurang memperhatikan nilainilai kontekstual sesuai sosial budaya setempat serta nilai-nilai arsitektural yang baik dan benar. Tidak terdapat tren kebudayaan sekaligus ruang bersama untuk warga saling berkomunikasi dan menuangkan minat bakatnya.

Kurangnya perkembangan pusat sosial yang informal di kawasan perumahan atau tempat untuk warga berkumpul mengakibatkan warga hanya berhubungan dengan tetangga terdekatnya. Selain itu, pertumbuhan perkembangan infrastruktur dan masyarakat di Indonesia khususnya kota Bekasi yang membuat terlalu banyak tekanan. Hal itulah yang kurang disadari oleh kebanyakan warga Bekasi, wadah pertunjukan seni diharapkan bisa menjadi wadah penampung komunitas seni di Bekasi sekaligus sebagai ruang kreatif yang mewadahi kreativitas atau ide yang dimiliki oleh masyarakat sekitar. Dengan program yang di usulkan di harapkan akan menjadi ruang rekreasi bagi warga kota Bekasi untuk bersenang senang dan berinteraksi dengan nilai (value) lebih, yaitu dengan edukasi mengenai tren kebudayaan dan edukasi mengenai minat bakat di bidang seni pertunjukan.

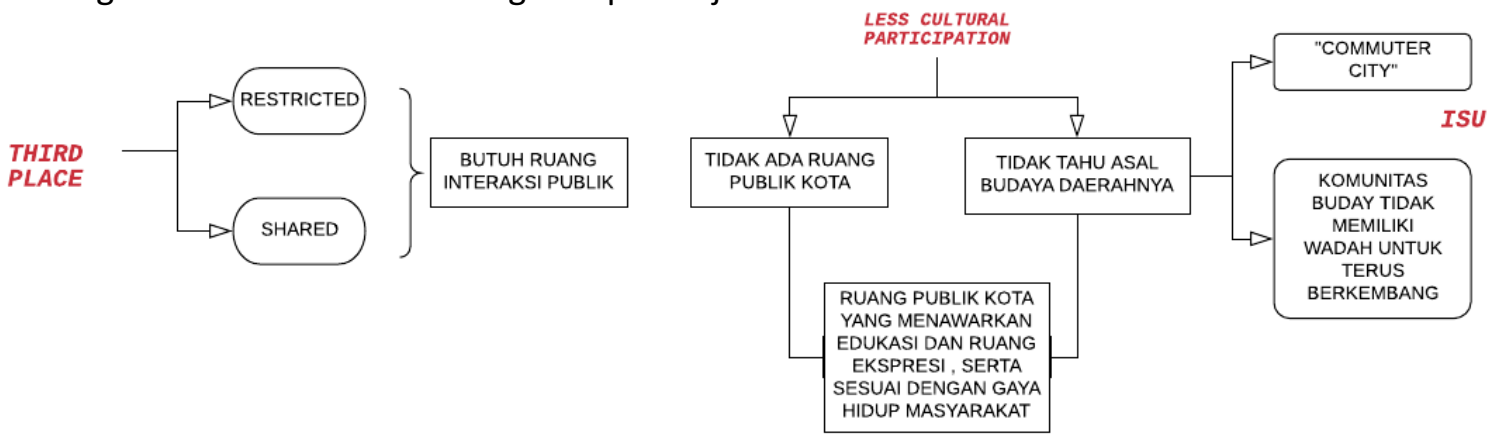

Gambar 1. Diagram Kompleksitas Proyek

Sumber: Penulis, 2019

Adapun tujuan dari penulisan ini adalah untuk penyediaan ruang publik yang baru untuk mewujudkan pusat komunitas di masa yang akan datang dengan menciptakan lingkungan kreatif yang berpusat pada keberlangsungan hidup masyarakat. Caranya adalah merangkul polaritas kota dengan alam untuk hidup berdampingan supaya menghasilkan lingkungan yang lebih menarik, menjadi sarana interaksi sosial dengan obyek program yang akan disampaikan sebagai pemersatu, mengakomodasi kota Bekasi menjadi tempat rekreasi edukatif, menggabungkan nilai sociability dan relaxation serta, menjadi sebuah gaya hidup dan sarana edukasi di Bekasi yang belum ada sebelumnya. 


\section{KAJIAN LITERATUR}

Istilah place erat kaitannya dengan teori space. Jika space berarti tiga dimensi yang membentuk place, sedangkan karakter diartikan sebagai suasana dari sebuah place. Edward Relp, Prospect of place, berpendapat bahwa ada hubungan antara lanskap, pengalaman keseharian dengan faktor sosial dan ekonomi dalam pembentukan sebuah ruang. Istilah place dikaitkan dengan hubungan antar lanskap, pengalaman keseharian dengan faktor sosial sebagai tempat-tempat yang unik, lanskap, ruang-ruang komunal dibandingkan dengan pengalaman dan lingkungan tertentu (Larice dan Macdonald, 2007).

Pengertian place bukanlah sesuatu yang abstrak atau sekedar berupa konsep, tetapi place adalah sebuah fenomena kehidupan yang mengandung unsur pengalaman langsung, mempunyai arti dan merupakan sesuatu yang nyata yang didalamnya terdapat aktivitas yang terjadi terus menerus. Keberadaan place sangatlah penting karena merupakan sumber dari sebuah identitas yang menunjukkan eksistensi individu maupun komunitas, bahkan lebih dari itu, place mempunyai hubungan yang emosional sangat dalam dan psikologi, baik itu seseorang maupun komunitas. Third place mengambil peran besar pada kehidupan masyarakat dan bisa mendefinisikan pengertian ruang. Third place tidak hanya untuk tempat rekreasi kasual atau aktivitas. Third place menjadi peran yang bisa berkontribusi dengan keseluruhan gaya hidup masyarakat. Untuk itu masyarakat perlu menyadari bahwa, third place menjadi aset yang tidak dapat diperdebatkan. Konsep third place ini cukup unik untuk proses perkembangan sebuah tempat karena, third place menerobos sebuah generasi dengan kesepakatan yang jauh lebih baik daripada karakteristik tempat lain (Oldenburg,2019).

Adapun karakteristik dari third place adalah sebagai berikut :

- Leveler (sama rata)

Kutipan dari sosiologis Richard Sennett bahwa setiap individu berpeluang untuk bersosialisasi ketika mereka memiliki perlindungan dari sesamanya.(Oldenburg,2019.)

Selayaknya perkotaan dan lingkungan di dalamnya untuk menawarkan perkumpulan yang kaya dan bervariasi, perlu ada neutral ground (tempat netral) di tempat setiap individu berkumpul. Apabila sebuah neutral ground sudah berdiri dari situ bisa timbul rasa intim, tempatnya serasa lebih informal dan hubungan yang terbangun lebih menghibur daripada di rumah.

\section{INFORMAL}

\section{MAKE A GOOD RELATION}

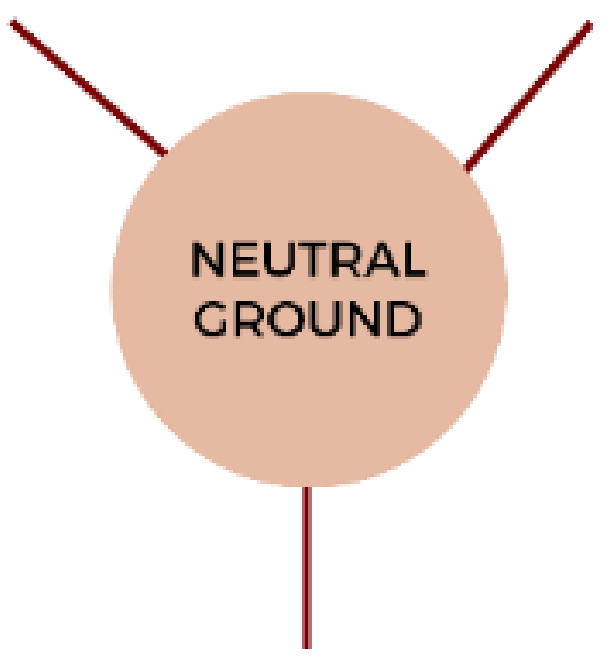

INTIMATE

Gambar 2. Diagram Keuntungan Neutral Ground di Lingkungan Sumber: Penulis, 2019 
- Percakapan adalah aktivitas utamanya

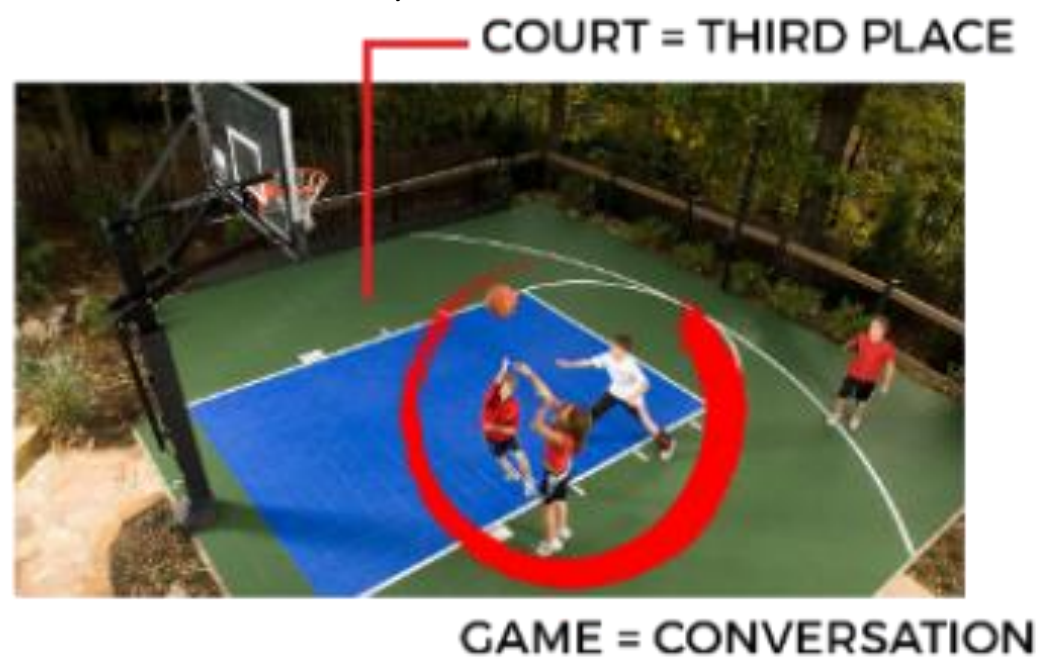

Gambar 3. Diagram Game Court

Sumber: Penulis, 2019

Berdiskusi adalah kegiatan yang membuat setiap individu semakin mengenal satu sama lain dan membuat lingkungan menjadi lebih nyaman. Dalam bercakap-cakap juga ada yang namanya Game of Manner atau permainan sikap. Situasi dramatik dari permainan tersebut akan menghasilkan minat yang menarik, yaitu akal dan keahlian. Hubungan dari third place dan percakapan ini bila digambarkan seperti sebuah lapangan olahraga dan permainan yang dimainkan di dalamnya.

- $\quad$ Aksesibilitas \& Akomodasi

Third place yang mempunyai pelayanan penuh dan baik adalah tempat yang paling dicari oleh setiap individu yang sedang diserang kesendirian dan rasa bosan. "Sebuah komunitas kehidupan yang nyata" menurut sosiologis Philip Slater, ketika individu itu pergi secara rutin ke sebuah lokasi yang diberikan mereka dapat bertemu dengan individu yang mereka kenal disana. Third place harus menjadi tempat yang selalu siap sedia melayani setiap individu yang membutuhkan sociability (bergaul) dan relaxation (hiburan) kapanpun. Artinya, third place harus selalu buka baik siang hari hingga malam hari.

a. Sociability (bergaul)

Bergaul dimulai dari lingkungan keluarga, tetangga, RT, RW, kelurahan sampai seterusnya. Saat bergaul juga ada etikanya, hampir sama dengan etika dalam memulai percakapan.

b. Relaxation (hiburan)

Hiburan dapat berupa musik, film, opera, drama, ataupun berupa permainan bahkan olahraga. Berwisata juga dapat dikatakan sebagai upaya hiburan dengan menjelajahi alam ataupun mempelajari budaya. Mengisi kegiatan di waktu senggang seperti membuat kerajinan, keterampilan, dan membaca.

Contoh industri hiburan langsung yang bersifat tradisional :

- Jenis hiburan langsung : sirkus, teater musikal, pentas seni, komedi, olahraga, konser.

- Industri musik : komposer, penyanyi, orkestra, dan aula konser

- Hiburan pameran : taman hiburan, pasar malam, pameran bertema, pameran dagang

Contoh industri media massa hari ini :

- Film : studio film, teater film, musik film

- Taman tema 
- Regulars/Membership

\section{Diskotek}

- Media baru : televisi web

- Industri mode

- Hiburan elektronik : permainan video

Di dalam third place pasti akan ada pengunjung-pengunjung tetap. Kunjungan yang sering dan dilakukan tetap sesuai jadwal ini nantinya dapat mempermudah individu untuk berkomunikasi. Pendatang baru juga sangat dibutuhkan supaya third place terus bertahan.

- Low profile

Third place juga bersifat lebih sederhana. Third place lebih memperhatikan masyarakat komunitas di lingkungan sekitar.

- Playful

Sebuah third place harus memiliki suasana yang menyenangkan sehingga setiap individu tertarik untuk melihat dan mengunjungi third place. Bukan hanya program-program yang ditawarkan dalam third place saja yang membuat suasana hati menjadi senang, tetapi dalam hal arsitektur juga. Desain third place juga perlu untuk menciptakan playful mood itu sendiri. Contohnya adalah Dongziguan Villagers Activity Center.

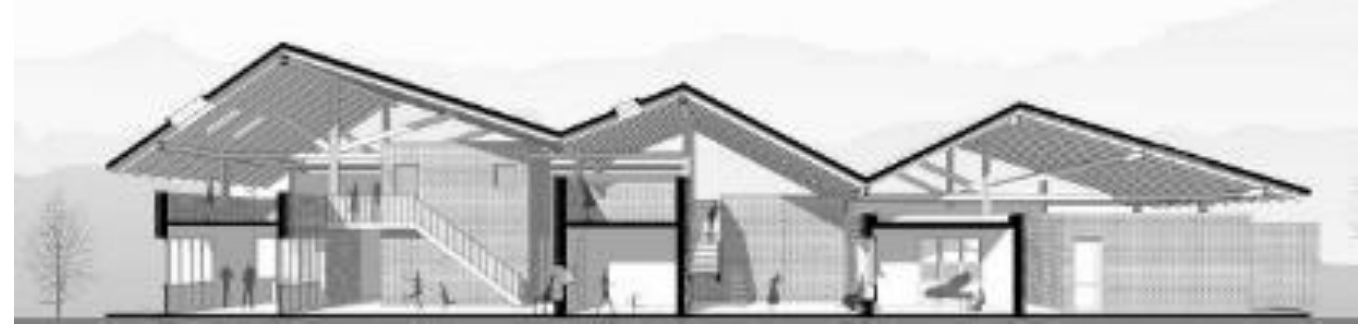

Gambar 4. Potongan Dongziguan Villagers Activity Center

Sumber: magaceen, 2019

\section{- A home away from home}

Karakter third place sebagian besar ditentukan oleh pengunjung regulernya dan ditandai oleh suasana hati yang menyenangkan, yang kontras dengan keterlibatan individu yang lebih serius di bidang lain. Meskipun pengaturannya sangat berbeda dari rumah, third place sangat mirip dengan rumah yang baik dalam kenyamanan dan dukungan psikologis yang meluas. Seperti itulah karakteristik third place yang tampaknya universal dan esensial untuk kehidupan publik informal yang sangat diperlukan.

\section{Performing Arts Space}

Performing arts (pertunjukan seni) mengacu pada transformasi dan kolaborasi berbagai bentuk seni. Istilah ini mewujudkan pemikiran dan kritik kreatif, yang meliputi analisis budaya visual kontemporer bersama dengan bentuk seni lainnya. Kebudayaan bukan berupa fakta-fakta statis, melainkan organisma hidup yang bersifat dinamis, sehingga cara berpartisipasi seseorang atau warga juga mengikuti perubahan-perubahan tersebut (Morrone,2006). Setiap orang diberikan peluang untuk memiliki akses dan sekaligus pilihan apakah akan berpartisipasi atau tidak. Kebijakan publik, khususnya kebudayaan, harus merefleksikan dan memberikan kontribusi terhadap konstruksi dari lingkungan yang memberikan jalan (enabling environment) bagi terpenuhinya hak setiap orang untuk mengakses dan berpartisipasi dalam kehidupan kebudayaan. Pengembangan seni, karya budaya, dan tradisi memiliki peran penting dalam meningkatkan apresiasi masyarakat dari generasi ke generasi. Insentif tidak hanya dalam bentuk 
materi namun juga dukungan. Sasaran program ini adalah untuk membangkitkan semangat nasionalisme, seni dan karya budaya merupakan sarana penghubung dan komunikasi yang mampu melampaui batas-batas geografis, etnis, agama, maupun strata sosial. Kreativitas karya budaya juga mampu memberikan nilai ekonomi dan menciptakan inovasi dalam penciptaan lapangan kerja menuju kesejahteraan masyarakat. Kemudian, masyarakat Bekasi banyak melibatkan diri dalam berbagai kegiatan (resmi, informal dan tradisional) yang membentuk vitalitas kehidupan budaya. Kesenian dapat dibedakan berdasarkan jenis dan bentuk, antara lain:

Berdasarkan Jenis :

a. Kesenian Tradisional yaitu suatu bentuk seni yang bersumber dan berakar, serta telah dirasakan sebagai milik oleh masyarakat di lingkungannya. Pengolahan didasarkan atas cita rasa masyarakat pendukung dan diterima sebagai tradisi.

b. Kesenian Modern yaitu merupakan seni yang penggarapannya didasarkan atas cita rasa masyarakat pendukungnya. Cita rasa baru umumnya merupakan pembaharuan atau penemuan sebagai akibat dari pengaruh luar.

Berdasarkan Bentuk:

a. Seni pertunjukan - Seni pertunjukan adalah karya seni yang menggunakan perantara atau media ekspresi bunyi, gerak, dan irama. Karya seni yang dipertunjukan bergerak dan hidup. Adapun seni pertunjukan terdiri dari seni tari, seni musik, dan seni drama. Karya seni pertunjukan dapat juga disebut sebagai hasil seni yang bergerak (dinamis), hal ini karena digerakkan atau dilakonkan oleh manusia, jadi yang diciptakan adalah patokan-patokan, irama, komposisi dari gerak ataupun suara.

b. Seni rupa (Visual art) - Seni rupa adalah cabang seni yang membentuk karya seni dengan media yang bisa ditangkap mata dan dirasakan dengan rabaan. Kesan ini diciptakan dengan mengolah konsep garis, bidang, bentuk, volume, warna, tekstur, dan pencahayaan dengan acuan estetika.

Pertunjukan atau performance art adalah karya seni yang melibatkan aksi individu atau kelompok di tempat dan waktu tertentu. Seni pertunjukan bisanya melibatkan empat unsur: waktu, ruang, tubuh si seniman dan hubungan seniman dengan penonton. Waktu dalam hal ini adalah rangkaian yang diperlukan dalam mengungkapkan bentuk-bentuk gerak dalam ruang tertentu sehingga tercapai ungkapan bentuk dan perpaduan gerak dalam waktu atau tempo tertentu. Ruang dibutuhkan oleh seniman untuk melakukan gerakan, kebutuhan ruang gerak berbeda-beda tergantung kebutuhan dan kesanggupan dari seniman itu sendiri.

Jenis seni pertunjukan Menurut A. Karim Achmad (1990), seni pertunjukan dibagi menjadi tiga macam, yaitu:

a. Seni Tari - Tari adalah gerak ritmis sebagian atau seluruh tubuh yang terdiri dari pola individual atau berkelompok yang disertai ekspresi tertentu. Media utama terletak pada gerak yang ditimbulkan oleh tubuh manusia yang diserasikan dengan ruang dan gerak dalam waktu. Jadi tari adalah seni sesaat dari ekspresi yang dipertunjukan dengan bentuk serta gaya tertentu lewat tubuh manusia yang bergerak dalam ruang.

b. Seni Musik - Musik adalah suatu bentuk seni yang merupakan cetusan ekspresi pikiran atau perasaan yang dikeluarkan secara teratur dalam bentuk bunyi.

c. Seni Peran / Drama adalah suatu bentuk seni dimana pengungkapanya berupa laku atau dialog. Sedikit berbeda dengan teater, dimana teater pengungkapannya selain dapat berupa laku atau dialog juga menggunakan tari, musik, dan segala sesuatu yang mendukung adanya suatu pertunjukan. 


\section{METODE}

Teori hanya sebagai kerangka umum suatu konsep. Teori bukanlah titik awal suatu perencanaan, letaknya bisa sebelum ataupun setelah praktek. Arsitektur merupakan perwujudan suatu konsep. Konsep merupakan hal yang sangat penting. Gambar akan muncul dengan energi dan bukti, namun terkadang gambar tidak muncul ketika konsep tidak menghendaki adanya gambar. Jangan melakukan apapun demi desain, tetapi bekerjalah hanya demi konsep dengan terus mengulang dan memperbaiki.

Proses perancangan akan menerapkan konsep Trans-Programming yaitu kombinasi dua program yang sifat dan konfigurasi spasialnya berbeda tanpa melihat kecocokannya. Third place merupakan penggabungan dari closeness dan openness, berarti sifat ruang yang tertutup (individuality) digabungkan dengan sifat ruang terbuka (activity). Dalam proyek third place akan digabungkan dua program yang berbeda namun, dapat bekerja sama dengan baik.

Metode yang digunakan untuk gubahan massa adalah metode perancangan tipologi. Tipologi merupakan kajian tentang tipe. Menurut Profesor Maldonado tipologi digunakan saat penyelesaian arsitektural yang berdasarkan program mengalami kesulitan, karena tidak semua dapat diamati dengan rinci, maka tipologi dapat membantu menyelesaikan masalah. Sedangkan menurut Aldo Rossi, tipologi arsitektur adalah obyek dan proses sekaligus. Bentuk-bentuk yang muncul menjadi tipe obyek sebagai pemulaan kreatif untuk menghasilkan obyek selanjutnya. Dalam ingatan kolektif, kita dapat menelusuri tipe.

Metode tipologi yang kali ini digunakan prosesnya akan melalui tahap analisa pada beberapa aspek yang digunakan oleh bangunan - bangunan ruang pertunjukan terdahulu dan dilihat bagaimana perkembangannya terhadap bangunan pertunjukan hingga tahun 2019. Setelah melalui tahap analisa makan hasilnya akan diterapkan pada proyek yang akan dirancang.

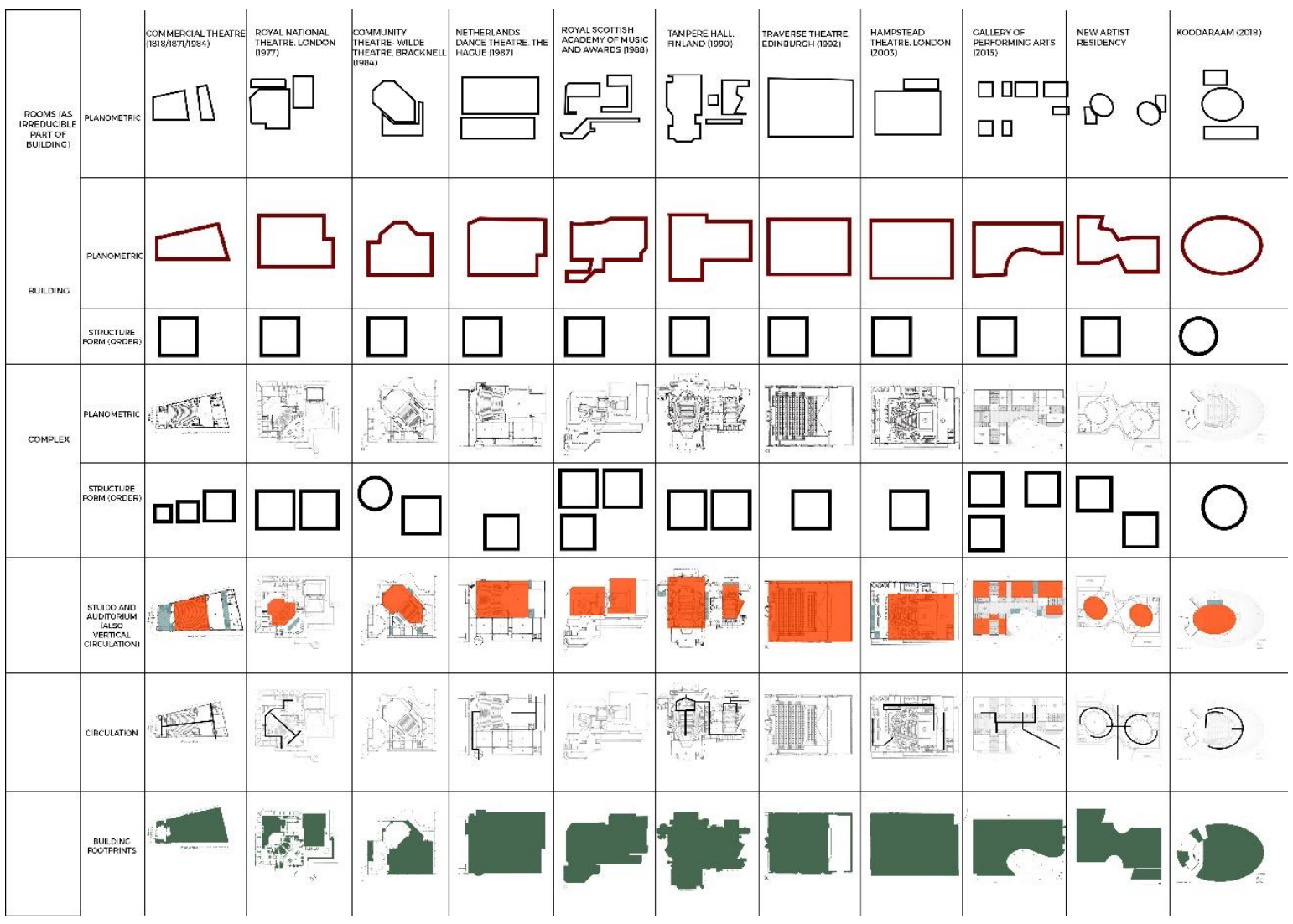

Gambar 5. Diagram Tipologi Bangunan Ruang Pertunjukan Sumber: Penulis, 2019 
Dapat disimpulkan bahwa dari beberapa aspek pada setiap bangunan performing art space tidak banyak berubah, yang terlihat berubah dengan sangat drastis hanya pada bagian denah dan sirkulasi, dimana seiring berkembangnya waktu maka bangunan performing art space dibuat menjadi semakin fleksibel tanpa terikat satu kegiatan. Setelah melalui tahap analisa tipologi bangunan performing art space lalu setelahnya masuk pada tahap menganalisa kawasan dan tapak perancangan proyek. Aspek - aspek yang dianalisa adalah yang berhubungan langsung terhadap pembangunan proyek seperti solid void area, ketinggian bangunan, bangunan sekitar, vegetasi, orientasi, drainase, kemacetan, view, dan akses.

\section{Analisis Studi Preseden}

Studi preseden yang digunakan sebagai referensi adalah:

a. KOODAARAM

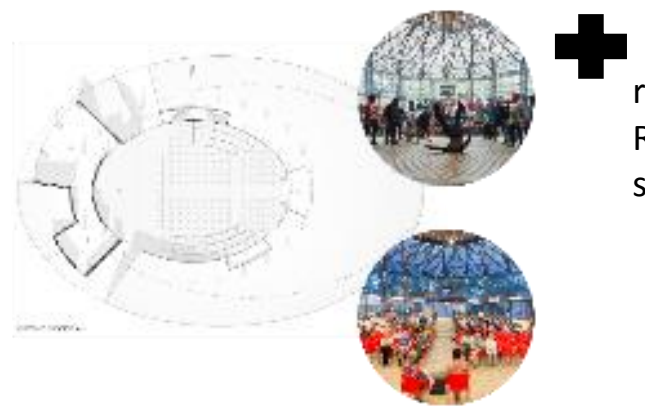

Hal yang menonjol dari KOODAARAM adalah ruang seni pertunjukkan yang sifatnya fleksibel. Ruang ini bisa dijadikan ruang olahraga, tempat seminar, launching buku, dan lain sebagainya.

Gambar 6. KOODARAAM

Sumber: archdaily,2019

b. Performing Arts Studio of the National Theater of Korea

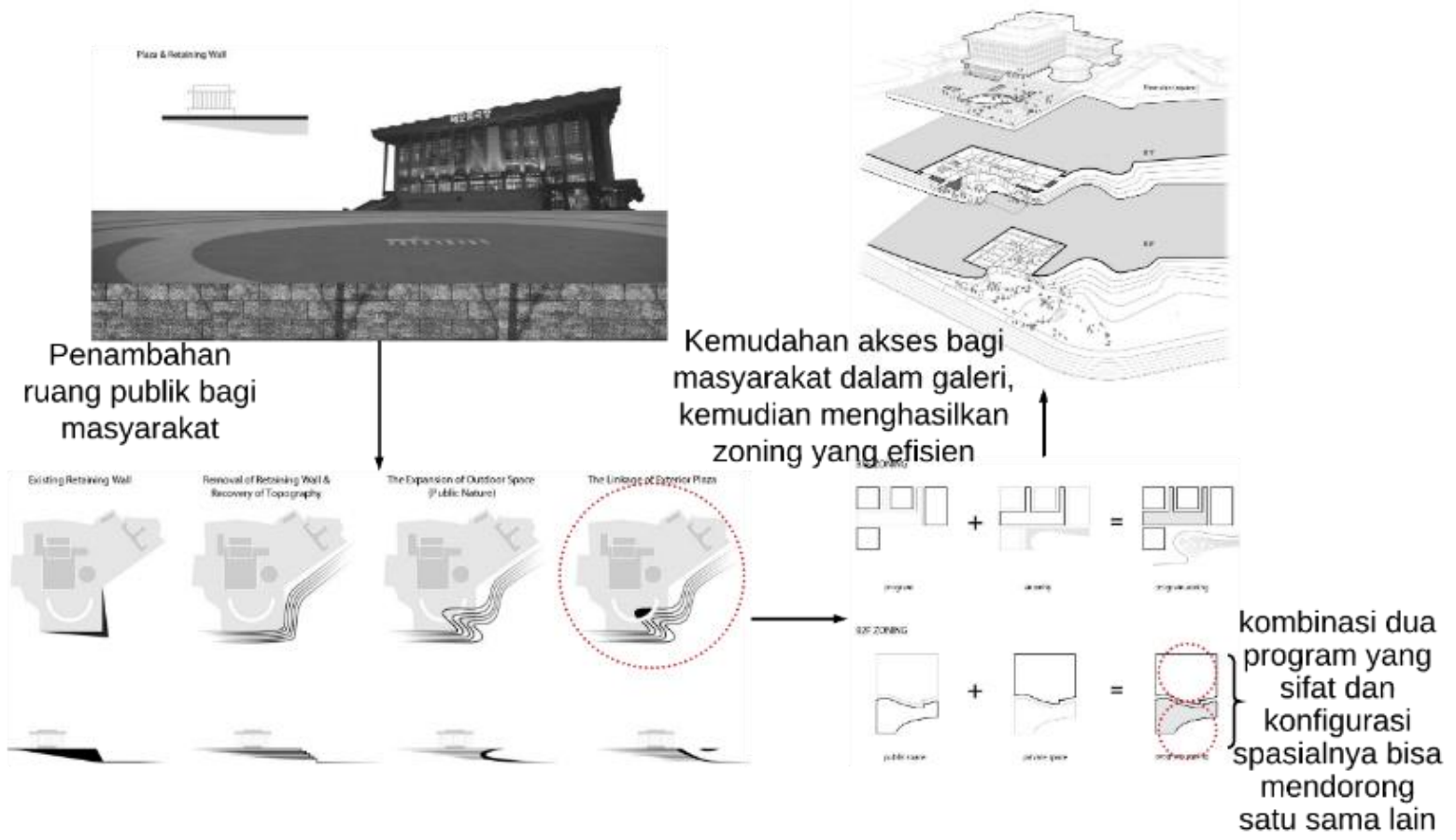

Gambar 7. Diagram Konsep Sumber: archdaily,2013 


\section{c. New Artist Residency}

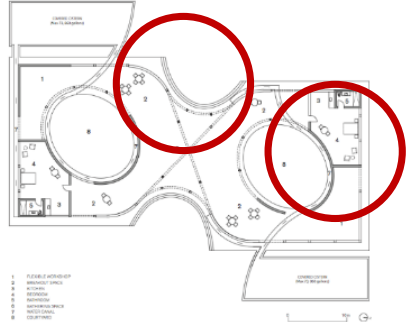

Gambar 8. Denah Lantai Dasar Sumber: archdaily,2015

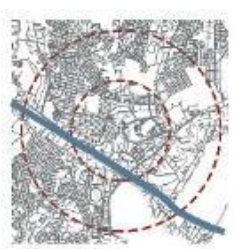

TRAIN NETWORK

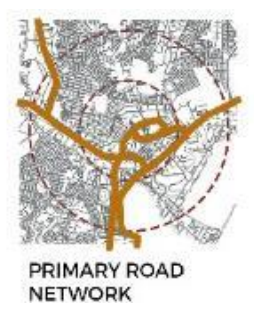
PRIMARY ROAD
NETWORK

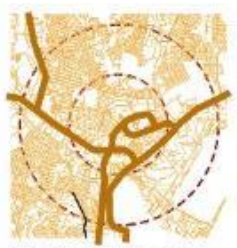

SECONDARY ROAD NETWORK
Terdapat ruang pameran yang fleksibel. Zoning dibagi menjadi dua dihubungkan dengan ruang gathering untuk acara berkumpul antar seniman dan warga lokal.

Sumber: Penulis, 2019

Gambar di atas adalah informasi tapak menjelaskan faktor-faktor sebagai pelengkap site. Terdapat jalur kereta, jalan primer, jalan kolektor, regenerasi air, zoning kawasan dan penghijauan di sekitar tapak.
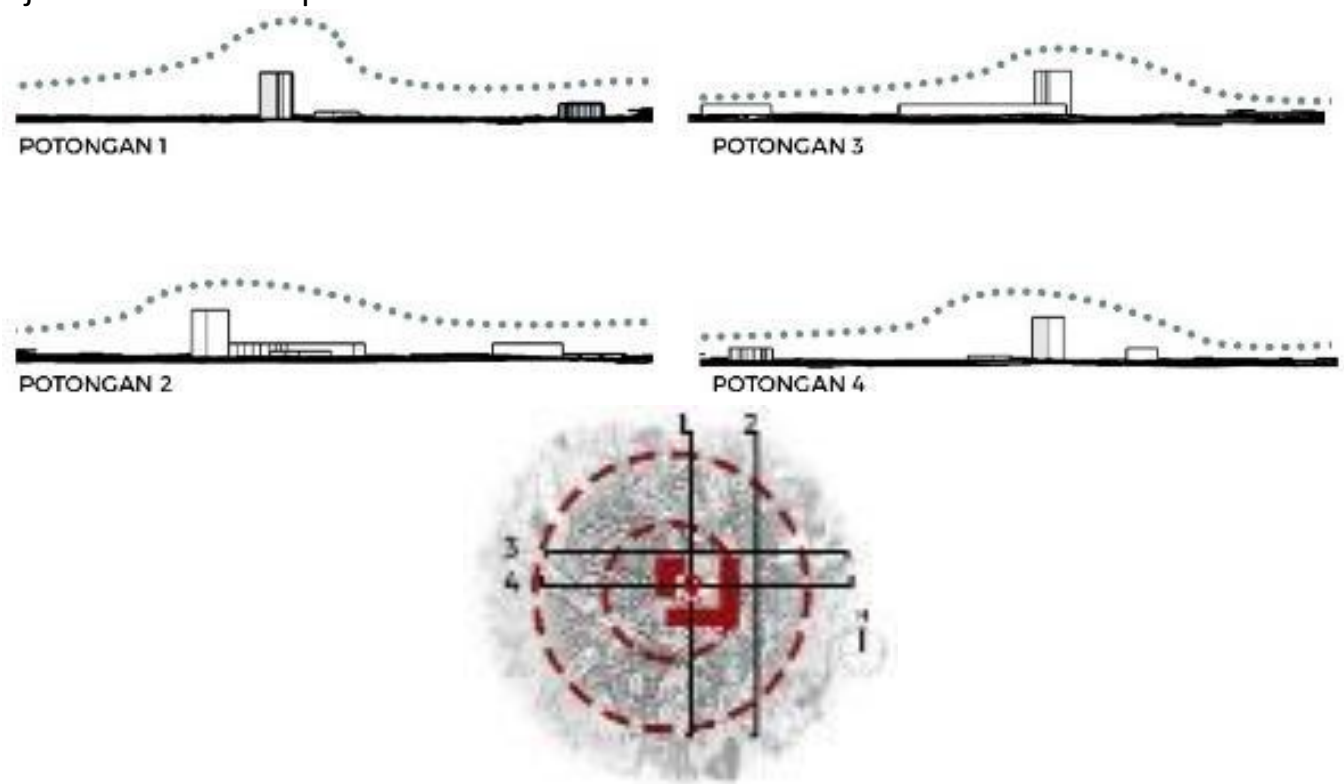

Gambar 10. Skyline Bangunan

Sumber: Penulis, 2019

Analisa ketinggian bangunan dilakukan dengan melihat skyline yang terbentuk dari bangunan - bangunan di sekitar tapak, dan melihat dimana sekiranya proyek akan terbangun sehingga tetap terlihat dari jalan besar dan mampu menjadi daya tarik untuk pengunjung. 

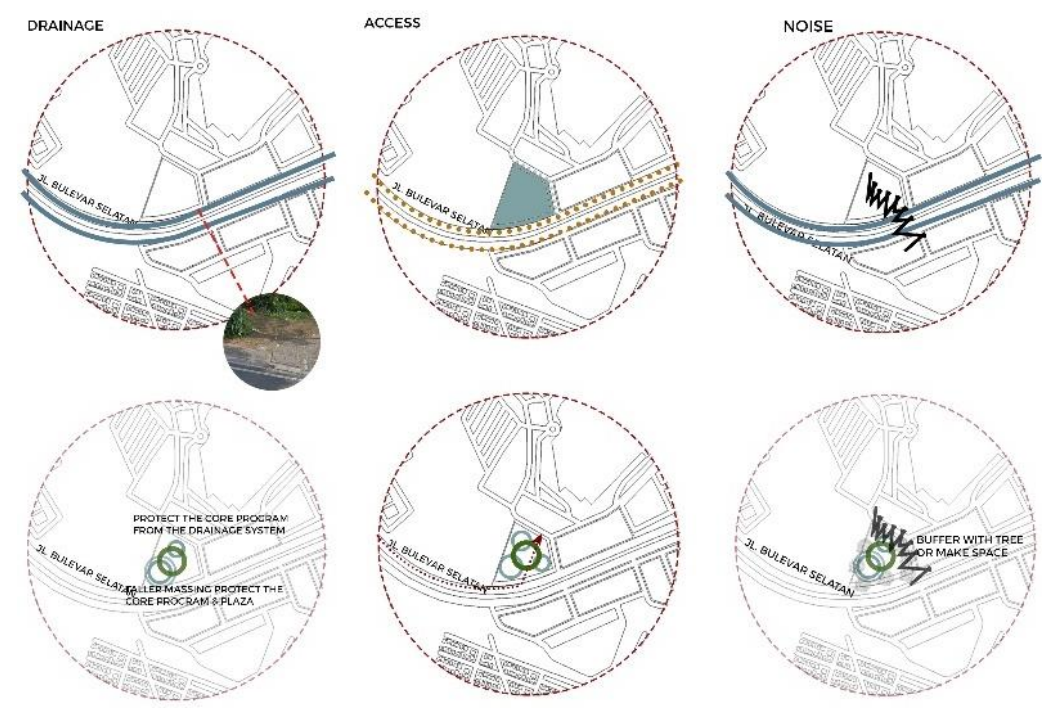

Gambar 11. Drainase, Akses dan Suara

Sumber: Penulis, 2019

Analisa drainase untuk menghindari core program dan plaza dari bau yang dihantarkan dari sistem drainase. Akses terbaik dari Jl. Bulevar Selatan di analisa sehingga pengunjung dapat mencapai core program. Analisa suara untuk menghindari suara terlalu berisik dari jalan raya maka, ditanam pepohonan untuk menyaring suara ke dalam program.
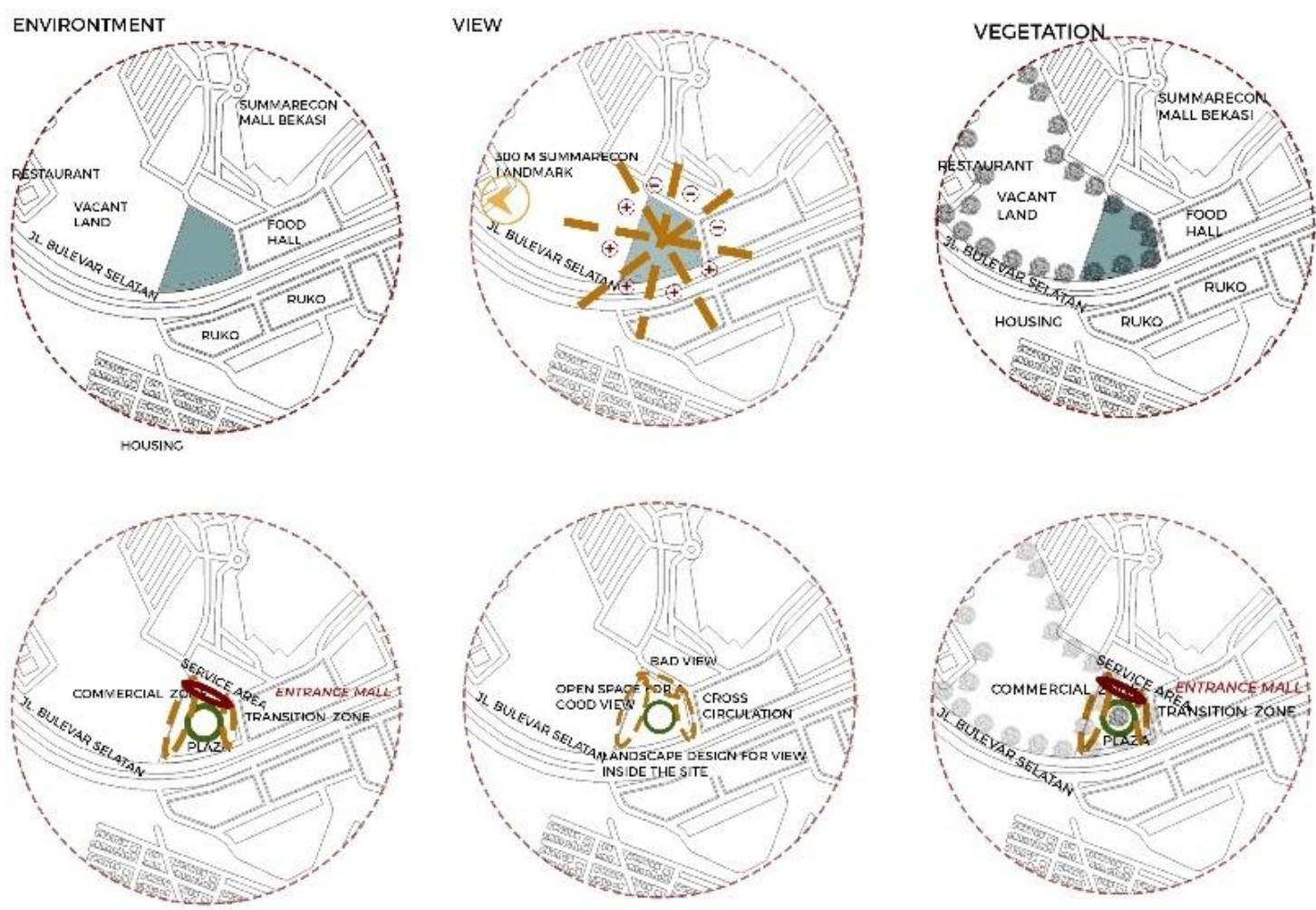

Gambar 12. Lingkungan, View dan Penghijauan Sumber: Penulis, 2019

Analisa lingkungan dan view untuk penempatan zoning program di dalam tapak. Sedangkan, analisa vegetasi dilakukan untuk melihat area hijau yang berada di sekitar tapak, hal ini bertujuan untuk menyeimbangkan area hijau dan area terbangun pada tapak. 


\section{DISKUSI DAN HASIL}
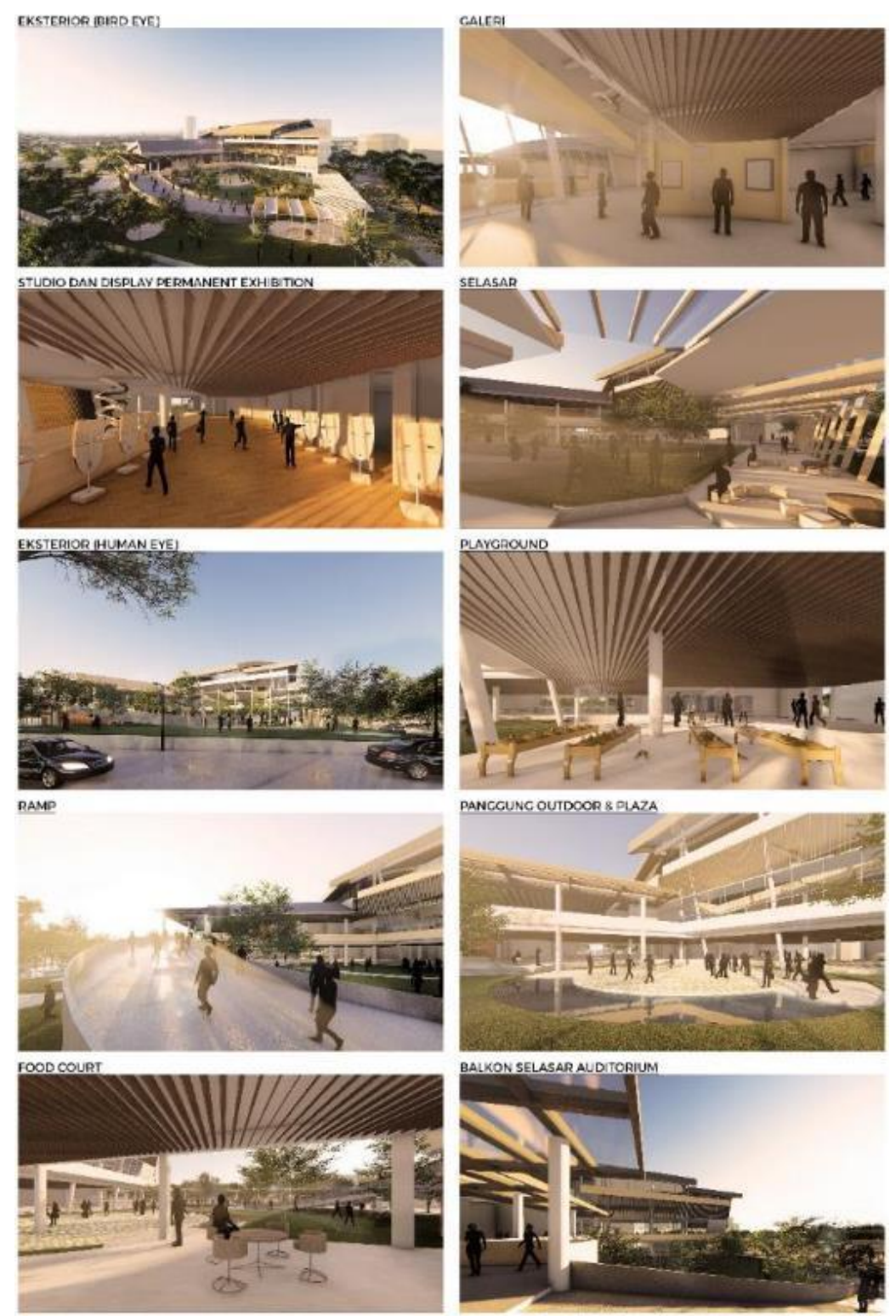

Gambar 13. Eksterior \& Interior Bangunan Sumber: Penulis, 2019

Berdasarkan hasil penelitian mulai dari proses metode perancangan untuk program dan metode perancangan tipologi untuk mempelajari sirkulasi dan bentuk, kemudian dilanjutkan dengan analisa tapak maka dihasilkan bangunan performing arts space yang sesuai dengan tiga program utama yaitu, ruang multifungsi berupa auditorium, galeri dan studio pelatihan.

Bangunan ini akan dibangun sebanyak empat lantai menyesuaikan dengan peraturan zonasi. Akan ada dua auditorium yang pertama untuk pertunjukan khusus untuk pertunjukan seni (tari, peran, dan musik) dan yang kedua adalah auditorium multifungsi (umum) bisa untuk showcase, peluncuran buku, ruang pertemuan dan ruang seminar. Ruangan galeri juga dibuat multifungsi terkadang bisa menjadi galeri secara keseluruhan atau dibagi-bagi dengan kegiatan pertunjukan seni untuk tari, bela diri (pencak silat) dan musik. Kemudian studio pelatihan yang bisa menjadi sanggar atau untuk privat. Dilengkapi dengan plaza yang berisi ruang pengantar dan food court. Selain itu dilengkapi dengan panggung outdoor dan pendopo untuk beristirahat dilengkapi dengan wifi dan tempat untuk mengisi daya baterai alat elektronik (hp, dsb.). 


\section{Lantai Dasar}

Area lantai dasar pada proyek ini di desain dengan konsep terbuka untuk publik, dimana lantai dasar akan terbuka kurang lebih $80 \%$ untuk pengunjung yang hadir. Area entrance juga bisa diakses dari tiga titik, dari kantor pengelola Mall, dari entrance Mall dan Jalan Bulevar Selatan. Area entrance utama terdapat pada sisi depan dan di sisi belakang ada entrance untuk kendaraan online.

Area yang diberi dinding hanya area service dan food court serta kantor pengelola. Jika dilihat pada gambar 11 maka area tersebut adalah yang diberi warna merah. Selain entrance, ada juga sirkulasi kendaraan menuju basement. Bangunan ini memiliki satu lantai basement dengan kapasitas total empat belas mobil dan 38 motor. Selain itu terdapat pula area service pada basement, serta ruang tunggu supir.

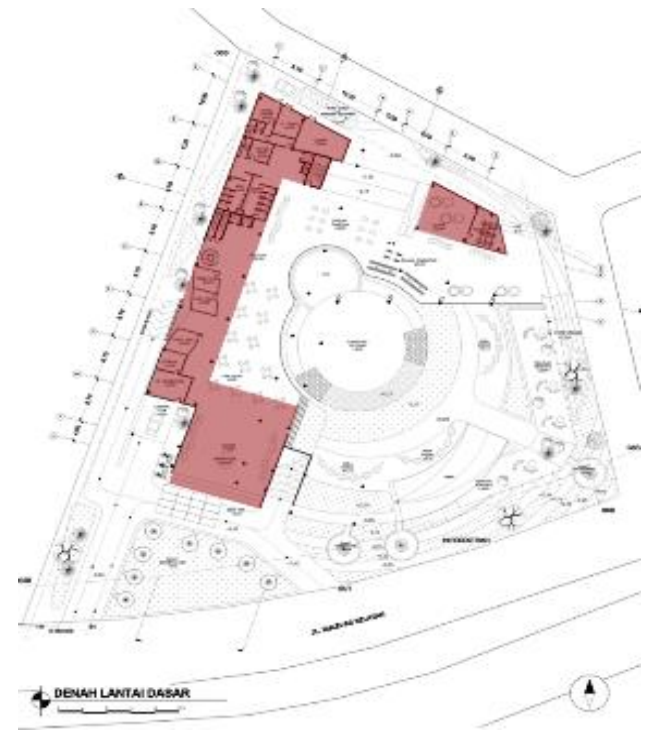

Gambar 14. Denah Lantai Dasar

Sumber: Penulis, 2019

\section{Area Penunjang}

Proyek ini memiliki empat lantai dan sebuah plaza. Area penunjang ini terletak di lantai tiga meliputi area retail, atm, ruang pengantar, studio, klinik, food court, dan galeri.
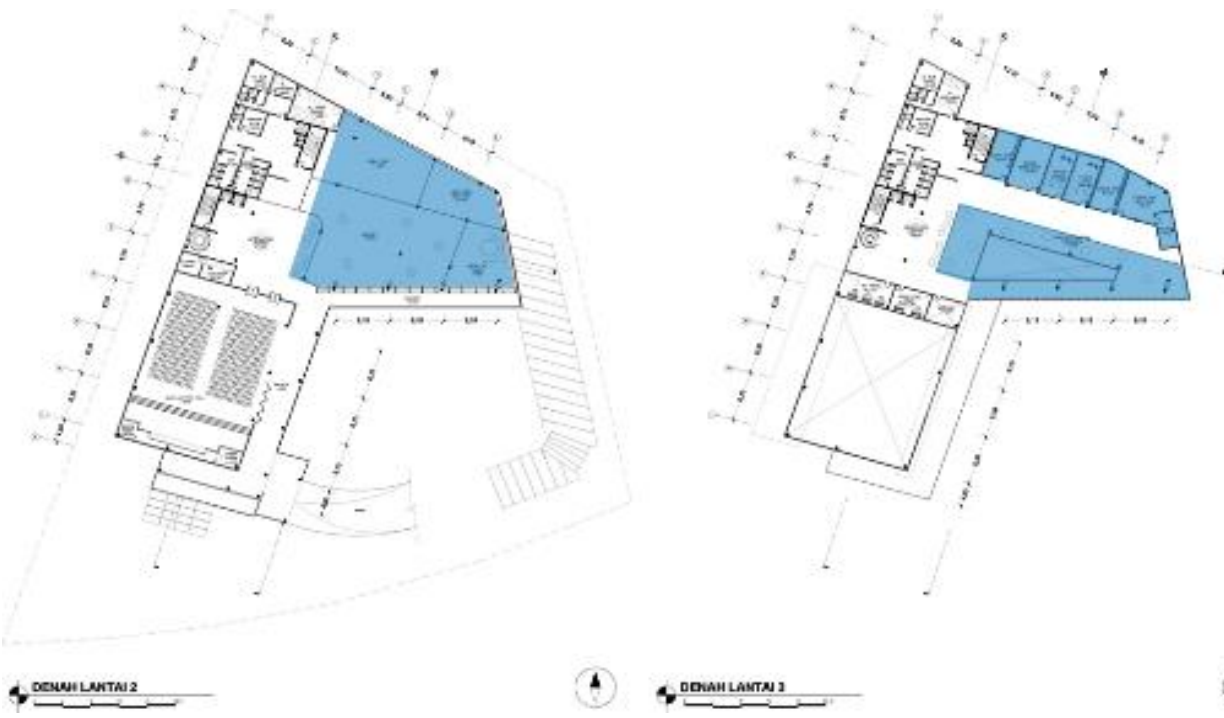

Gambar 15. Denah Area Penunjang

Sumber: Penulis, 2019 
Denah lantai dua memiliki program penunjang berupa ruang galeri dan ruang pertunjukan terbuka. Hal ini disebabkan letaknya sangat berdekatan dengan lantai dasar dimana zonasinya dapat dikatakan sangan publik. Sehingga dengan akses vertikal berupa tangga dan lift, galeri yang diletakkan pada lantai dua akan mudah dipasarkan. Selain itu, terdapat pula program penunjang berupa studio. Studio menjadi ruang untuk berlatih dan bertukar pikiran. Tentu saja studio di desain sesuai dengan kebutuhan tiap jenis seni pertunjukan. Di depan studio terdapat pameran permanen yang juga diharapkan menjadi pusat perhatian pengunjung. Sehingga terjadi komunikasi antara pengguna studio dan pengamat pameran.

\section{Performance Arts Hall Sebagai Third Place}

Area performance arts hall menjadi andalan pada proyek ini, dimana third place bisa menggunakan program ini sebagai tempat untuk kelompok saling berinteraksi dan menonton pertunjukan. Area performance arts hall diletakkan pada dua lantai yaitu lantai dua dan empat desain entrance dipisahkan dari area penunjang.
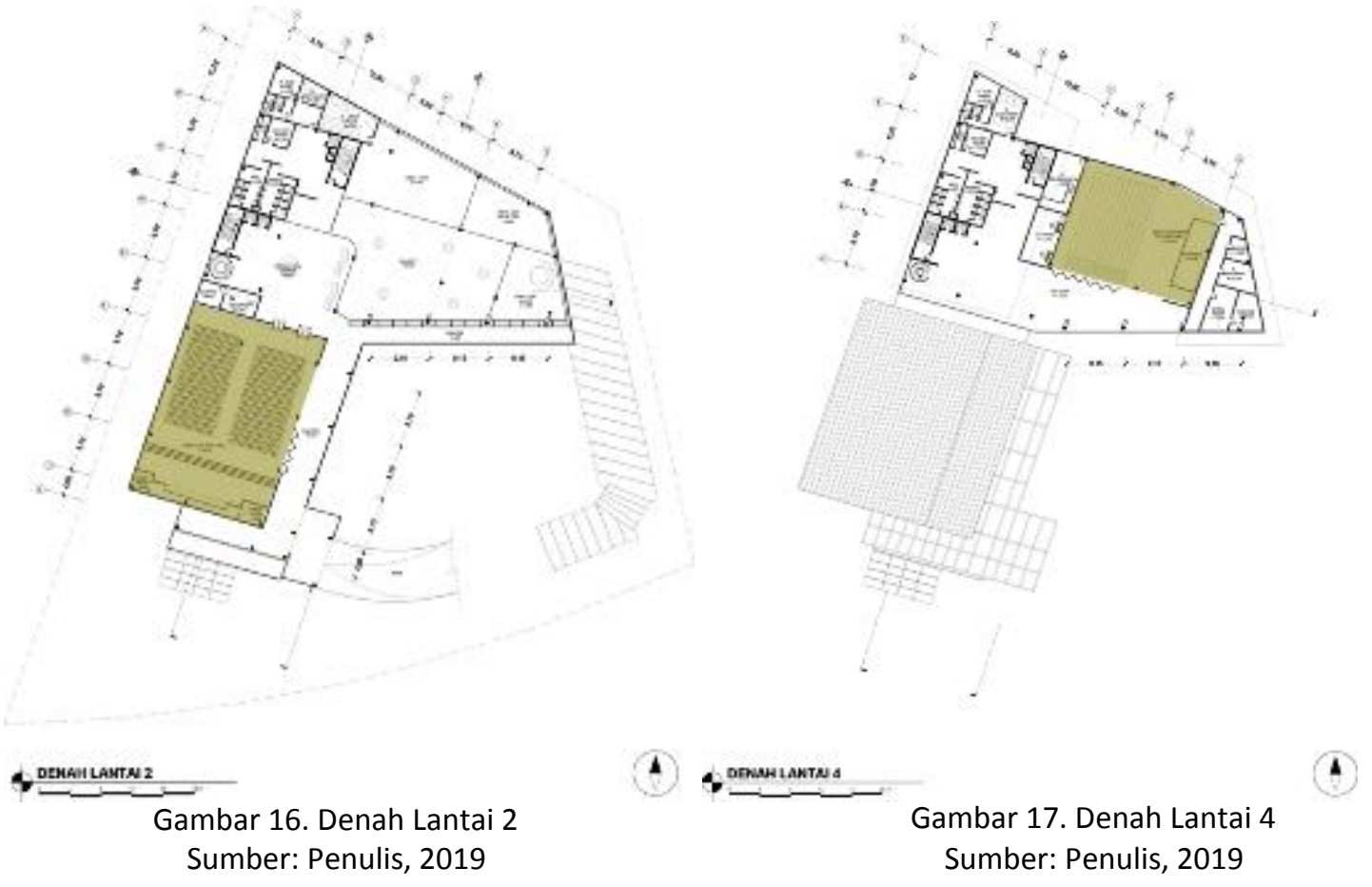

Area performance arts hall dibagi menjadi dua. Di lantai dua untuk pertunjukan khusus dan lebih terbuka. Sedangkan, di lantai empat untuk acara seperti seminar, peluncuran buku dan rapat.

\section{KESIMPULAN DAN SARAN}

Third place menjadi peran yang bisa berkontribusi dengan keseluruhan gaya hidup masyarakat. Perancangan Wadah Pertunjukan Seni di Bekasi dengan tinggi empat lantai dan mengutamakan konsep fleksibilitas ruang untuk mengurangi sekat-sekat kegiatan dalam suatu ruang, dirancang dengan mengkombinasi tipologi dari pendekatan dari Open Architecture (The Architecture of Third Place).

Proyek ini diharapkan berguna sehingga masyarakat Bekasi menampung kegiatan seni dan kebudayaan di kota Bekasi. Diharapkan tujuan proyek untuk menjawab rumusan dan permasalahan serta, menambah pengetahuan sehingga yang diajukan di awal dapat terpenuhi. Permasalahan yang ada pada lokasi, kurangnya edukasi mengenai kebudayaan kota Bekasi dan kurangnya ruang ekspresi hiburan bagi warga Bekasi atau turis mancanegara. 
Sebaiknya proyek ini perlu dipertimbangkan oleh Pemerintah Daerah Kota Bekasi untuk memprogramkan performance arts hall dan galeri untuk meningkatkan rasa kebudayaan pada masyarakat kota Bekasi. Apabila proyek dibagun diharapkan setelahnya dapat terus mewadahi kegiatan kesenian dan komunitas seni budaya serta, dirawat dengan baik oleh pemakai.

\section{REFERENSI}

Achmad, A.K. (1980). Analisis Kebudayaan, DEPDIKBUD, Direktorat Kesenian Jakarta, hal 815.

Badriya, Y. (2016). 8 Karakteristik Kebudayaan Lengkap. Retrieved December 6, 2016 , from https://ilmuseni.com/seni-budaya/karakteristik-kebudayaan Daerah, Badan Perencanaan Pembangunan. (2016). Rencana Pembangunan Jangka Menengah Kota Bekasi Tahun 20132018 Revisi. Retrieved from http://bappeda.jabarprov.go.id/wpcontent/uploads/2016/07/BAB-II-FINAL.pdf

Furuto, A. (2013). Performing Arts Studio of the National Theatre of Korea Second Prize Winning Proposal. Retrieved April 6, 2013, from https://www.archdaily.com/353853/performingarts-studio-of-the-national-theatre-of-korea-second-prize-winning-proposal-archiplan

Goldthorpe, John H, Dan Chan, Tak W. (2005). Social Stratification of Cultural Participation : Theatre and Cinema, the Visual Arts and Reading. Oxford.

Journal, W. (2018). Mengenal Kemunculan dan Perkembangan Performance Arts di Indonesia. Retrieved May, 2018, from https://www.whiteboardjournal.com/ideas/mengenalkemunculan-dan-perkembangan-performance-art-di-indonesia/

Kementerian Pendidikan dan Kebudayaan. (2016). Analisis Partisipasi Kebudayaan.

Laksmana, F. I. (2014). Karakteristik Seni dan Budaya Indonesia. Retrieved May, 2014 , from http://febridrawingartist.blogspot.com/2014/05/karakteristik-seni-dan-budayaindonesia.html

Maggiora, Martial Vial Della. (2019, Juli 18). KOODAARAM Kochi-Muziris Pavilion. Retrieved from https://www.archdaily.com/921181/koodaaram-kochi-muziris-pavilion-anagramarchitects

Mori, T. (2015). New Artist Residency. Retrieved March 12, 2015, from https://www.archdaily.com/608096/new-artist-residency-in-senegal-toshiko-mori

Morrone, A. (2006). Guidelines for Measuring Cultural Participation. Montreal. UNESCO Institute for Statistics.

UNESCO. (2009). UNESCO Framework of Cultural Stratistics, Montreal. UNESCO Institute for Statistics.

Oldenburg, R. (1989). The Great Good Place. Da Capo Press : Cambridge.

Rencana Pembangunan Jangka Menengah Daerah Kota Bekasi. (2018). 